\title{
An instrument to measure job satisfaction of nursing home administrators Nicholas G Castle*
}

\author{
Address: A649 Crabtree Hall, Graduate School of Public Health, 130 DeSoto Street, Pittsburgh, PA 15261, USA \\ Email: Nicholas G Castle* - castleN@pitt.edu \\ * Corresponding author
}

Published: 09 October 2006

BMC Medical Research Methodology 2006, 6:47 doi:10.1186/147I-2288-6-47

This article is available from: http://www.biomedcentral.com/I47I-2288/6/47

(C) 2006 Castle; licensee BioMed Central Ltd.

This is an Open Access article distributed under the terms of the Creative Commons Attribution License (http://creativecommons.org/licenses/by/2.0), which permits unrestricted use, distribution, and reproduction in any medium, provided the original work is properly cited.
Received: 16 May 2006

Accepted: 09 October 2006

\begin{abstract}
Background: The psychometric properties of the nursing home administrator job satisfaction questionnaire (NHA-JSQ) are presented, and the steps used to develop this instrument.

Methods: The NHA-JSQ subscales were developed from pilot survey activities with 93 administrators, content analysis, and a research panel. The resulting survey was sent to I,000 nursing home administrators. Factor analyses were used to determine the psychometric properties of the instrument.
\end{abstract}

Results: Of the I,000 surveys mailed, 721 usable surveys were returned (72 percent response rate). The factor analyses show that the items were representative of six underlying factors (i.e., coworkers, work demands, work content, work load, work skills, and rewards).

Conclusion: The NHA-JSQ represents a short, psychometrically sound job satisfaction instrument for use in nursing homes.

\section{Background}

Job satisfaction is defined as "the favorableness or unfavorableness with which employees view their work" [1]. Some recent research would suggest that job satisfaction of employees within an organization is related to an organization's ability to change [2]. Since a consistent theme in the literature for the past 20 years (or more) has been the inability of some nursing homes to change in a meaningful way, especially in the area of quality of care [3], in this context improving job satisfaction may be important in improving some aspects of the industry.

Job satisfaction of nursing home administrators (NHAs) may be especially important, because administrators can have a pervasive influence on facility performance and quality of care [4]. Castle [5], for example, has shown a positive association between NHA turnover and the resident outcomes of catheterization, restraint use, pressure ulcers, psychoactive medications, and quality of care deficiencies. Smith, Shortell, and Saxberg describe NHAs as "the critical variable affecting quality of care" [6]. Singh and Schwab [7] have examined the organizational destabilization that can occur when NHAs turnover [7]. Resident satisfaction would also appear to be influenced by NHAs [8]. Given the importance of NHAs and their potential impact on quality, a valid and reliable instrument to assess their job satisfaction is desirable. However, we found that no instrument currently exists that was developed specifically for this purpose. In this investigation, we use data from 721 NHAs to develop such an instrument. 
Several generic job satisfaction instruments are readily available for use [9]. These include the Job Description Index [10], revised Index of Work Satisfaction [11], modified Job Description Index [12], and the Measure of Job Satisfaction [13], to name just a few. Gillies, Foreman, and Pettengill [14] reviewed job satisfaction instruments, and found none to be extensively used or developed with long-term care settings in mind. This by itself is not necessarily problematic, as these instruments were designed for general applications. But what is problematic is that studies using existing job satisfaction instruments in longterm care settings have generally been dissatisfied with the performance of these preexisting instruments [15].

Moreover, other factors may also reduce the performance of these preexisting instruments for use with NHAs. NHAs work in a fairly unique environment, with a flat administrative structure, large number of unskilled workers, and high turnover. That is, the determinants of NHAs job satisfaction may not be different from that of other professionals, but existing instruments may not be sensitive to the unique work environment. A flat administrative structure may reduce the number of professional peers with whom NHAs can collaborate. NHAs may be professionally isolated (i.e., coworkers may be an important influence on NHAs' job satisfaction). Moreover, empirical analyses [16] have shown the flat administrative structure to increase the work load of NHAs. In many instances, to accomplish objectives, NHAs must undertake initiatives themselves (i.e., work demands may be an important influence on NHAs' job satisfaction). The large number of unskilled workers may not adequately match the NHAs' work skills. For example, NHA licensure includes knowledge of quality assurance and regulations; however, the unskilled workers that constitute a vast majority of the workforce may be more concerned with staffing schedules and the social climate (i.e., work skills may be an important influence on NHAs' job satisfaction). Both unskilled workers and other top managers (i.e., the Director of Nursing) characteristically have high levels of turnover. This high staff turnover may reduce teamwork (i.e., teamwork may be an important influence on NHAs' job satisfaction). This unique environment would seem to indicate that a specific NHA job satisfaction instrument could be useful. Also, anecdotal evidence from hundreds of contacts with NHAs in the recent past, suggested to us that a specific NHA job-satisfaction instrument could better capture job satisfaction than preexisting instruments.

Studies identified examining job satisfaction of caregivers in long-term care settings are shown in Table 1. The results (Table 1) show job satisfaction is clearly important for caregivers in nursing homes. For example, in six of the 19 studies listed, lower job satisfaction was associated with turnover/absenteeism. However, we do note that the vast majority of these studies have not examined NHAs. These previous studies have used differing job satisfaction instruments. Also, it is clear that existing job satisfaction instruments use relatively few satisfaction subscales. Moreover, no instrument included all of the job satisfaction items/subscales identified above as potentially important for NHAs (i.e., coworkers, work demands, work skills, and teamwork).

In this case, the use of relatively few satisfaction subscales in existing instruments was important for a second reason. That is, since we know little regarding NHAs' job satisfaction, we sought to identify a wide range of subscales; thus providing us with more information. We also found some job satisfaction instruments used dichotomous response options. We were interested in using an instrument with multiple response categories, so that we could examine the relative degree of satisfaction and dissatisfaction of NHAs, which of course is not possible using a dichotomous scale. Many existing job satisfaction instruments use a relatively large number of questions. To increase the likelihood that the final instrument would be used by the industry, we considered it important to minimize the number of questions. It was because of these more-desirable instrument requirements, and the general unsuitability of existing instruments, that we developed the nursing home administrator job satisfaction questionnaire (NHA-JSQ).

\section{Methods \\ Job satisfaction questionnaire Subscales}

In developing the NHA-JSQ, our first consideration was to determine what areas of concern the questions should address (i.e., subscales). Therefore, using open-ended questions and mail surveys, we asked 93 administrators to list specific areas of their jobs that they believed were most (least) important, and gave them most (least) satisfaction. That is, we believe that NHAs receive satisfaction from their job activities. This follows the "met expectations" theory of job satisfaction, whereby job satisfaction is believed to be the result of the agency between the individual and employer [17]. We used this approach, because we wanted an instrument that was both theoretically grounded and psychometrically sound.

The responses were transcribed and then collapsed into similar areas/themes by using content analysis [18]. We excluded variables that seemed more likely to moderate job satisfaction rather than be a dimension of job satisfaction. For example, concerns regarding federal and state regulations were not included, although many NHAs voiced concerns in these areas. A list of 11 candidate subscales was identified, and an additional 73 NHAs in a mail survey were asked to rate the top five areas. After taking 
Table I: Summary of Job Satisfaction Studies in Long-Term Care Settings

\begin{tabular}{|c|c|c|c|c|}
\hline Author(s) & $\begin{array}{l}\text { Job Satisfaction } \\
\text { Instrument }\end{array}$ & Job Satisfaction Domains & Sample Size and Setting & Significant Findings \\
\hline
\end{tabular}

\begin{tabular}{|c|c|c|c|c|}
\hline \multirow[t]{5}{*}{ Murphy (2004) [30] } & Job Descriptive Index (JDI) & $\begin{array}{l}\text { Work on present job } \\
\text { Pay }\end{array}$ & I49 nursing home administrators in lowa & Most dissatisfied with coworkers and pay \\
\hline & & Opportunities for promotion & & \\
\hline & & Supervision & & \\
\hline & & Co-workers & & \\
\hline & & Job in general & & \\
\hline
\end{tabular}

Parsons et al. (2003) [31] _ Modified from Herzberg Personal op

(1966) Supervision

Moyle et al. (2003) [32

N/A

Chou, Boldy, \& Lee (2002) [13,33] Measure of Job Satisfaction Professional support (MJS)

Will \& Simmons (1999) [34]

Job Descriptive Index (JDI)

Atchison (1998) [35]

Job Diagnostic Survey
Benefits

Coworker support

Social rewards

Task rewards

Workplace flexibility

Team environment

Optimal resident care

Personal satisfaction

Workload

Training

Team spirit/co-workers

Pay

Opportunities for promotion

Supervision

Co-workers

Job in general

550 NAs in 70 facilities in Louisiana

27 RNs and NAs in one facility in Australia

Seventy facilities with 610 nursing home staff and 373 hostel care staff in Australia

Satisfaction

Job security

Coworkers

Sense of accomplishment

Helping other people

Dissatisfaction

Pay/benefits
423 NAs in 29 nursing homes in Ohio

283 NAs in 24 nursing homes

Most dissatisfied with pay, benefits, and recognition

Satisfaction was linked to workplace flexibility, residents, team environment, and better resident care

Job satisfaction is associated with professional support

Job satisfaction lowest for security, growth/development, socialization, and challenges
Satisfied most with work and least with pay 
₹ Table I: Summary of Job Satisfaction Studies in Long-Term Care Settings (Continued)

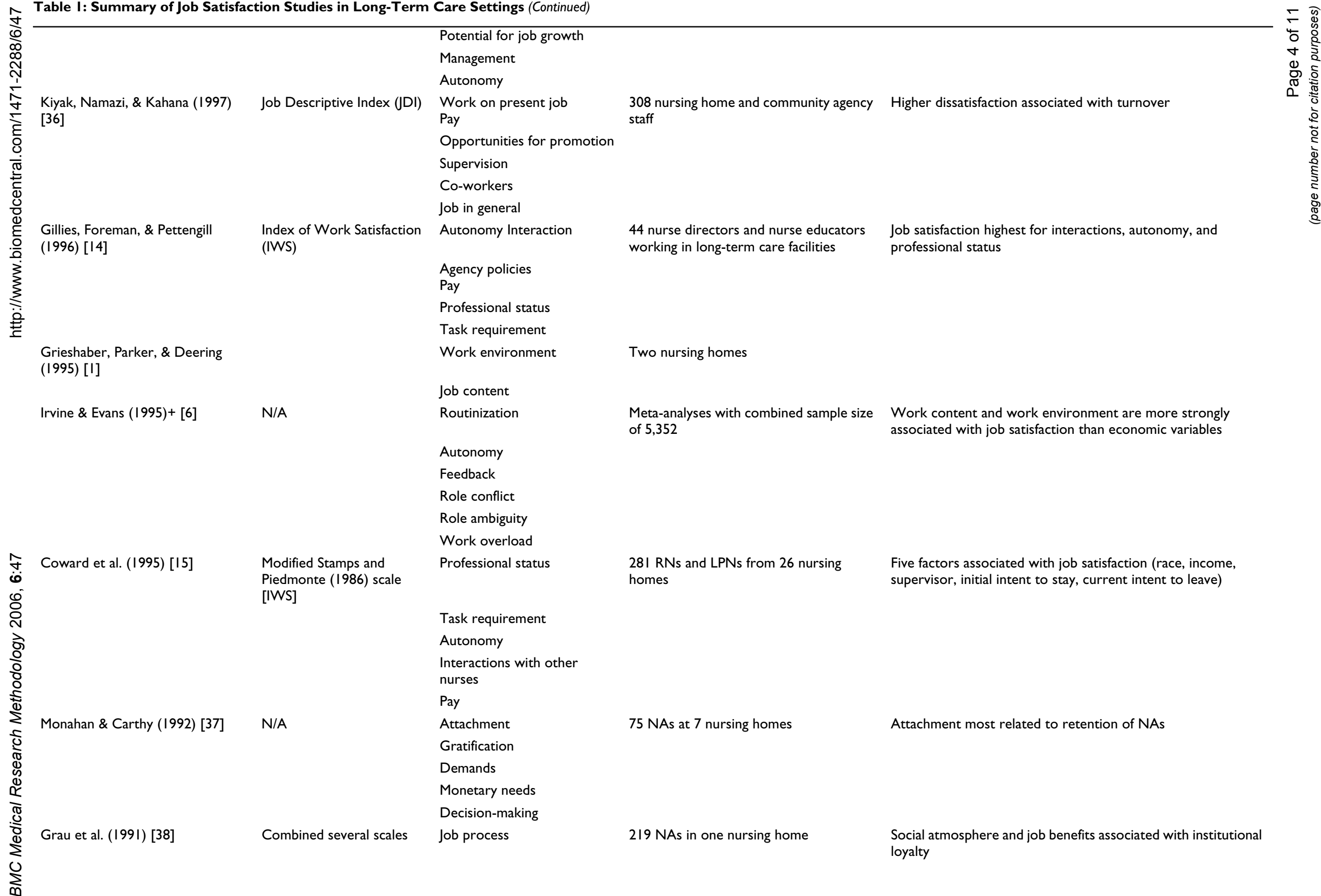


于 Table I: Summary of Job Satisfaction Studies in Long-Term Care Settings (Continued)

\begin{tabular}{|c|c|c|c|c|}
\hline & & $\begin{array}{l}\text { Attitudes toward } \\
\text { administration }\end{array}$ & & \\
\hline & & Social atmosphere & & \\
\hline & & Job benefits & & \\
\hline & & Job tasks & & \\
\hline $\begin{array}{l}\text { Anderson, Aird, \& Haslam (1991) } \\
\text { [39] }\end{array}$ & NG & None & 212 nursing staff in 6 nursing homes & $\begin{array}{l}\text { Nursing staff have high levels of satisfaction, but is associated } \\
\text { with absenteeism }\end{array}$ \\
\hline \multirow[t]{3}{*}{ Humphris \& Turner (1989) [40] } & Porter (1962) scale & Working conditions & $\begin{array}{l}84 \text { nurses at a unit for the elderly } \\
\text { severely mentally infirm }\end{array}$ & Low satisfaction was associated with turnover from unit \\
\hline & & Emotional climate & & \\
\hline & & General & & \\
\hline \multirow[t]{9}{*}{ Mullins et al. (I988) [4I] } & Job Satisfaction Survey (JSS) & Pay & $\begin{array}{l}\text { Heads of departments }(n=439) \text { from } 46 \\
\text { nursing homes }\end{array}$ & Most satisfied when individual efforts are rewarded \\
\hline & & Promotion & & \\
\hline & & Supervision & & \\
\hline & & Benefits & & \\
\hline & & Rewards/appreciation & & \\
\hline & & Working conditions & & \\
\hline & & Coworkers & & \\
\hline & & Nature of job & & \\
\hline & & Communication & & \\
\hline \multirow{5}{*}{$\begin{array}{l}\text { Deckard, Hicks \& Rountree (1986) } \\
\text { [42] }\end{array}$} & Job Diagnostic Survey (JDS) & Skill variety & 340 nurses from a nursing home chain & Job satisfaction was similar to norms in other occupations \\
\hline & & Task identity & & \\
\hline & & Task significance & & \\
\hline & & Autonomy & & \\
\hline & & Job feedback & & \\
\hline Waxman et al. (1984) [43] & $\begin{array}{l}\text { Minnesota Satisfaction } \\
\text { Scale }\end{array}$ & Job Satisfaction Scale & $\begin{array}{l}234 \text { NAs in } 7 \text { facilities, uses } 20 \text { questions } \\
\text { for overall job satisfaction score }\end{array}$ & Positive association between job satisfaction and turnover \\
\hline \multirow[t]{4}{*}{ Bergman et al. (1984) [44] } & None & Job & $\begin{array}{l}\text { I } 2 \text { long-term care facilities and } 432 \text { RNs, } \\
\text { LPNs, and NAs }\end{array}$ & Descriptive results provided \\
\hline & & $\begin{array}{l}\text { Knowledge, skill, and } \\
\text { attitudes }\end{array}$ & & \\
\hline & & Autonomy & & \\
\hline & & Stress & & \\
\hline
\end{tabular}

NA = Nurse Aide; RN = Registered Nurse; LPN = Licensed Practical Nurse.

$+=$ This study is a meta-analysis, and does not include only long-term care studies.

NG = Not given; N/A = Not applicable. 
the average score for each subscale, we found a drop in the over-all rating for the seventh subscale. Based on this result, we considered six areas of job satisfaction to be most important from the perspective of NHAs.

Clearly, what is included in each domain depends somewhat on the definition used to operationalize each domain. We attempted to label our six domains (and defined each domain) to be consistent with prior studies [19]. This process included examining the domains (and their definitions) of the studies listed in Table 1. We labeled the domains as: Coworkers, Work Demands, Work Content, Work Load, Work Skills, and Rewards.

'Coworkers' represents relations with other workers in the facility; 'Work Demands' represents resources and demands of the job; 'Work Content' represents the complexity and challenges of the work; 'Work Load' represents time pressures; 'Work Skills' represents preparation for the position; and, 'Rewards' represents benefits of the job.

\section{Item development}

To develop items for the NHA-JSQ, we examined questions from previously published job satisfaction instruments ( $\mathrm{n}=237$ questions) and specific comments provided by NHAs in the mailings described above $(\mathrm{n}=$ 83 comments). Items that seemed to fit the six subscales listed above were chosen, and these items were rewritten: (1) to conform to the scaling requirements of the survey (described below); (2) to be relevant to NHAs (i.e., face validity); and (3) to be relevant to the nursing home context (i.e., content validity). We then had a six-member research team, consisting of experts and practitioners in survey development, gerontology, geriatrics, and longterm care, choose their candidate items from this initial item pool. These experts were asked to pick three questions in each satisfaction subscale, which they thought best captured the information. The five most highly rated questions in each area were included in our pilot instrument.

\section{Response scale}

Examining five different types of response scales, recent research has shown that a visual analogue rating scale from 1 to 10 (i.e., a graphic scale) was both the most-popular scale among elders, and was least prone to response bias [20]. This prior study was conducted on communitydwelling elders, and not NHAs. Nevertheless, the issue of lack of response variability is common to both job satisfaction [6,17] and elder satisfaction surveys. Therefore, we also investigated the use of this graphic scale with NHAs. In face-to-face interviews we conducted with NHAs $(\mathrm{N}=$ 27 ), they preferred a 1 to 10 graphic rating scale; therefore, this response scale was used in the NHA-JSQ.

\section{Sources of data}

Data used in this investigation to validate the pilot NHAJSQ described above came from a mail survey of NHAs. The NHA-JSQ was mailed to 1,000 NHAs located in two states, New York (NY) and Pennsylvania (PA). These states were chosen as a convenient sample, and only two states were used because we had limited resources for this research and we needed to limit the sample size.

For this survey mailing, a random sample of approximately 70 percent of facilities was chosen from each state's pool of eligible facilities. Eligible nursing homes were defined as those participating in Medicare and/or Medicaid certification, which includes approximately 97 percent of all nursing homes. We used this eligibility definition because these are the nursing homes included in the Online Survey, Certification, and Reporting (OSCAR) system data, which was used to identify the mailing address of these facilities. At the time of this study (spring 2004), eligible facilities included 673 nursing homes from NY and 749 from PA. In addition, we excluded owners from the analyses $(\mathrm{N}=32)$, but this could only be done after data collection, using a self-reported measure. These owner/ administrators were excluded because they are likely able to influence their work experience, including schedule, pay, and work content.

The mailing to NHAs included the survey, letter of introduction, and postage-paid reply envelope. In addition, we included a manuscript we had published in a nursing home trade magazine. Included in the letter of introduction, we indicated that a similar manuscript would be written from the current survey, and aggregate results could be sent directly to the administrator.

The OSCAR was also used as a minor source of data, primarily for descriptive analyses. The OSCAR is conducted by state licensure and certification agencies as part of the Medicare/Medicaid certification process, and includes almost all nursing homes in the U.S. (see [21] for a more extensive description of this data). Despite some potential validity and reliability issues (see [22]), the OSCAR data is widely used. For example, the OSCAR is often used by researchers as a secondary source of nursing home characteristics [3]. Given that the OSCAR was a minor source of data for our analyses, these validity/reliability issues with the OSCAR data were of little consequence for the analyses presented.

\section{Analyses}

Descriptive analyses are first presented consisting of the percent or mean for characteristics of the NHAs and characteristics of the nursing homes in the sample. In addition, we used bivariate comparisons for respondent and non-respondent facilities using the OSCAR data. 
The NHA characteristics are self-evident, and are not described further. The nursing home characteristics used are bed size, ownership, chain membership, Medicaid occupancy, overall-resident census, case mix (using Activities of Daily Living [ADLs] and dementia), deficiency citations, staff turnover, and staffing levels. The number of beds in the facility is used as a measure of facility size. Two classes of facility ownership are used, for-profit and notfor-profit. Public facilities, such as state and locally run nursing homes, represent a minor market presence and were thus included in the not-for-profit class of ownership. Two classes of chain membership are also used, chain and non-chain. Medicaid occupancy represents the number of residents paid for by the Medicaid program, divided by the total number of all residents (multiplied by 100 to create a percent). Average resident census represents the total number of residents divided by the total number of beds (multiplied by 100 to create a percent). For each of three ADL questions (eating, toileting, and transferring) in the OSCAR, we assign a score from 0 to 3 by using no assistance, moderate need for assistance, and high degree of need for assistance, respectively. We then sum these scores. Higher scores indicate a greater average ADL impairment within the facility. Dementia represents the number of residents with dementia, divided by the total number of all residents (multiplied by 100 to create a percent). Deficiency citations are a count of the number of citations given to the facility in the most-recent licensure/certification survey. Staff turnover was determined using the percent of staff leaving the facility (voluntary or involuntary) during the previous year. Staffing levels represent the number of full-time equivalent (FTE) staff employed per 100 beds, and includes full-time, part-time, and temporary staff.

The characteristics of the NHAs and characteristics of the nursing homes in the sample were used to provide descriptive statistics. The NHAs' responses to the job satisfaction items were used to develop the NHA-JSQ. In this development process, the first analytic objective was to reduce the larger set of items to a smaller set, such that this smaller set of items would adequately represent the factor structure. The second objective was to report the applied psychometric properties of the NHA-JSQ.

Factor analyses were used to test the extent to which the items in each domain appeared to represent the same underlying construct; that is, to measure the degree of congruence between the domains of interest and the questions used to measure these attributes. Varimax rotation was used and a factor-loading criterion of 40 and uniqueness of $<.90$ were used to retain items.

As McHorney, Ware, Lu, and Sherbourne [23] point out, in many cases reporting standard psychometric properties may still not be sufficient in many cases to make an accurate judgment regarding the actual performance of an instrument when in use. These authors recommend reporting the applied psychometric properties of instruments, such as the completeness of data, score distributions (i.e., ceiling and floor effects), item-scale consistency, and reliability of domain scores. Following these recommendations, the percent of NHAs' not providing responses for each question was determined. This information on non-response is important because a score for each scale cannot be confidently computed if a high number of individual items comprising that scale is missing [23]. Score distributions include floor and ceiling effects; although, for job satisfaction scores, ceiling effects are usually of most interest. In our case, these are calculated by reporting the percent of responses with a rating of 1 (floor) and 10 (ceiling). Item-scale internal consistency was determined, using Cronbach's alpha for each subscale, and represents the degree to which items correlate within each subscale.

\section{Results}

Seven hundred and twenty-one responses were received from non-owner NHAs (response rate $=72$ percent). The response rate varied little across the states, with PA having a response rate of 74 percent $(n=337)$ and NY 69 percent $(\mathrm{n}=295)$. Most (76 percent) of the questionnaires were returned by mail within one month. Also, because we were able to link facilities with OSCAR data, we determined that no significant differences on facility characteristics (i.e., bed size, ownership, chain membership, Medicaid census, and staffing levels) existed for respondents, compared to non-respondents.

Table 2 presents descriptive statistics of NHAs, along with facility characteristics. Similar to other studies in this area, NHAs were most likely to have a Masters degree or higher (67 percent), and be a member of a professional society (91 percent). No differences between the state samples were observed (not reported).

Table 3 presents descriptive statistics and psychometric properties of the NHA-JSQ. This consists of 18 items. Cronbach's alphas for the domains are shown in the first column, and all were higher than the usually recommended level of 0.70 [23]. The primary factor loadings from the factor analyses are shown in the second column. All loadings exceeded the minimum cutoff of 0.40 , indicating that the items were representative of the underlying factors. In addition, the groupings of items (i.e., emergent factor structure) were the same as those proposed in the pilot instrument, as shown by the eigenvalues greater than 1.0, indicating a single factor solution for each domain. These eigenvalues were 4.32 (coworkers), 3.37 (work 
Table 2: Descriptive Statistics of Nursing Home Administrators and Nursing Homes

\begin{tabular}{|c|c|}
\hline Characteristic & Percent or Mean (Std.) \\
\hline \multicolumn{2}{|l|}{ Nursing Home Administrators } \\
\hline Gender (Female) & $54 \%$ \\
\hline Age (years) & $52(8.6)$ \\
\hline \multicolumn{2}{|l|}{ Highest level of education: } \\
\hline High School & $25 \%$ \\
\hline Bachelors degree & $8 \%$ \\
\hline Masters degree or higher & $67 \%$ \\
\hline Member of professional society/organization & $91 \%$ \\
\hline Number of places employed as an administrator & 7.4 \\
\hline Tenure as administrator in current facility (years) & $4.7(4.3)$ \\
\hline Tenure as an administrator (years) & $16.9(9.6)$ \\
\hline \multicolumn{2}{|l|}{ Nursing Homes } \\
\hline Organizational size & $137(102)$ \\
\hline For-profit ownership & $46 \%$ \\
\hline Chain membership & $35 \%$ \\
\hline Medicaid occupancy & $57 \%$ \\
\hline Average census & $91 \%$ \\
\hline Resident ADLs & $1.25(0.98)$ \\
\hline Dementia & $0.47(0.18)$ \\
\hline Deficiency citations & $4.36(3.72)$ \\
\hline $\mathrm{RN}$ turnover & $76 \%$ \\
\hline LPN turnover & $78 \%$ \\
\hline NA turnover & $107 \%$ \\
\hline FTE RNs per 100 beds & $9.76(7.6 I)$ \\
\hline FTE LPNs per 100 beds & $14.06(9.54)$ \\
\hline FTE NAs per 100 beds & $36.36(9.06)$ \\
\hline
\end{tabular}

FTE = full-time equivalent; RN = Registered Nurse; LPN = Licensed Practical Nurse; NA = Nurse Aide; ADL = Activities of Daily Living.

demand), 2.26 (work content), 2.02 (workload), 1.82 (work skills), and 1.69 (rewards).

The percent of NHAs not providing responses for each question was low, and averaged less than 1.0 percent. The means and standard deviations show that in several cases the distributions are slightly skewed to the positive end of the scales. Although it should be noted that, for all questions, the full range of scores was used (results not shown). The floor effects are negligible; whereas, the ceiling effects were slightly higher. The lowest ceiling effect score was 1.1 percent and the highest 19.3 percent.

The item-scale internal consistency analyses (corrected for overlap) show that the correlation of items within indexes were in all cases higher than those with other indexes (not shown). McHorney et al. [23] recommend use of a measure of correlation of greater than .40 in item-scale internal consistency analysis, and our items achieved or exceed this level in all cases.

\section{Discussion}

Due to the importance of nurses in clinical outcomes, The American Nurses Association (ANA) has advocated the development and use of a nurse-sensitive job satisfaction measure [24]. That is, a job satisfaction measure that is more relevant to nurses. The ANA believes that a job satisfaction instrument more sensitive to the nurses' work environment may be of greater use in work-improvement activities. The same may also be true for NHAs. As described previously, job satisfaction of NHAs may have important implications for quality of care and their job environment would seem somewhat unique. Due to the importance of NHAs in the nursing home, we advocate the use of an administrator-sensitive job satisfaction measure.

The NHA-JSQ represents a first step in the development of an administrator-sensitive job satisfaction instrument. The NHA-JSQ uses a simple graphic scale and is purposefully brief. This response scale and limited number of questions enables easy use by providers. Our experience shows that a typical respondent will take less than ten minutes to answer the survey questions. For users, data entry takes less than three minutes for each returned survey. Although, even with the NHA-JSQ, some users may still find it useful to receive instructions on using this instrument. 
Table 3: Psychometric Properties of the Nursing Home Administrator Job Satisfaction Questionnaire $(\mathbf{N}=\mathbf{7 2} \mathrm{I})$

\begin{tabular}{|c|c|c|c|c|c|c|c|c|}
\hline Item/Domain 1,2 & $\begin{array}{l}\text { Cronbach's } \\
\text { alpha } \\
\text { coefficients }\end{array}$ & $\begin{array}{c}\text { Primary } \\
\text { Factor } \\
\text { Loadings }\end{array}$ & $\begin{array}{c}\text { Missing } \\
\text { responses }\end{array}$ & Floor & Ceiling & Mean & $\begin{array}{l}\text { Standard } \\
\text { deviation }\end{array}$ & $\begin{array}{l}\text { Item-Scale } \\
\text { correlation }\end{array}$ \\
\hline Coworkers & 0.74 & & & & & & & \\
\hline Rate the people you work with & & 0.75 & $0.28 \%$ & $4.9 \%$ & $4.3 \%$ & 6.54 & 1.67 & 0.69 \\
\hline $\begin{array}{l}\text { Rate whether you feel part of a team } \\
\text { effort }\end{array}$ & & 0.73 & $0.14 \%$ & $0.4 \%$ & $1.4 \%$ & 7.23 & 1.82 & 0.62 \\
\hline Rate co-operation among staff & & 0.70 & $0.28 \%$ & $3.3 \%$ & $1.1 \%$ & 7.69 & 2.14 & 0.58 \\
\hline $\begin{array}{l}\text { Rate whether staff place reasonable } \\
\text { demands on you }\end{array}$ & & 0.70 & $0.14 \%$ & $0.14 \%$ & $7.6 \%$ & 3.87 & 2.46 & 0.58 \\
\hline Work Demands & 0.78 & & & & & & & \\
\hline $\begin{array}{l}\text { Rate the support available to you in } \\
\text { your job }\end{array}$ & & 0.60 & $0.27 \%$ & $10.6 \%$ & $18.0 \%$ & 7.28 & 1.52 & 0.83 \\
\hline $\begin{array}{l}\text { Rate the opportunities you have to } \\
\text { discuss your concerns }\end{array}$ & & 0.60 & $0.27 \%$ & $1.4 \%$ & $4.3 \%$ & 6.72 & 1.46 & 0.81 \\
\hline $\begin{array}{l}\text { Rate the demands residents and family } \\
\text { place on you }\end{array}$ & & 0.60 & $0.14 \%$ & $4.2 \%$ & $9.7 \%$ & 4.98 & 2.12 & 0.79 \\
\hline $\begin{array}{l}\text { Rate whether you feel you are doing a } \\
\text { good job }\end{array}$ & & 0.57 & $0.28 \%$ & $0.56 \%$ & $7.2 \%$ & 7.44 & 1.54 & 0.72 \\
\hline Work Content & 0.72 & & & & & & & \\
\hline $\begin{array}{l}\text { Rate how much you enjoy working } \\
\text { with residents }\end{array}$ & & 0.61 & $0.14 \%$ & $0.28 \%$ & $1.7 \%$ & 6.81 & 1.97 & 0.71 \\
\hline $\begin{array}{l}\text { Rate how your role influences the } \\
\text { lives of residents }\end{array}$ & & 0.60 & $0.14 \%$ & $5.3 \%$ & $1.4 \%$ & 7.26 & 2.29 & 0.69 \\
\hline $\begin{array}{l}\text { Rate your closeness to residents and } \\
\text { families }\end{array}$ & & 0.56 & $0.28 \%$ & $5.1 \%$ & $12.9 \%$ & 8.04 & 1.64 & 0.64 \\
\hline $\begin{array}{l}\text { Rate the amount of autonomy you } \\
\text { have }\end{array}$ & & 0.51 & $0.28 \%$ & $0.14 \%$ & $3.7 \%$ & 6.75 & 1.99 & 0.56 \\
\hline Work Load & 0.73 & & & & & & & \\
\hline Rate your workload & & 0.58 & $0.27 \%$ & $0.14 \%$ & $11.5 \%$ & 7.09 & 2.58 & 0.72 \\
\hline Rate your work schedule & & 0.54 & $0.14 \%$ & $0.27 \%$ & $6.3 \%$ & 6.98 & 2.59 & 0.72 \\
\hline Work Skills & 0.70 & & & & & & & \\
\hline $\begin{array}{l}\text { Rate whether the demands of your job } \\
\text { are compatible with your work skills }\end{array}$ & & 0.52 & $0.14 \%$ & $0.42 \%$ & $14.0 \%$ & 7.69 & 2.14 & 0.60 \\
\hline $\begin{array}{l}\text { Rate the adequacy of the training you } \\
\text { have to perform your job }\end{array}$ & & 0.51 & $0.27 \%$ & $0.27 \%$ & $19.3 \%$ & 8.54 & 1.31 & 0.60 \\
\hline Rewards & 0.80 & & & & & & & \\
\hline Rate how fairly you are paid & & 0.72 & $0.14 \%$ & $0.42 \%$ & $14.0 \%$ & 7.69 & 2.14 & 0.60 \\
\hline $\begin{array}{l}\text { Rate your chances for further } \\
\text { advancement }\end{array}$ & & 0.71 & $0.27 \%$ & $0.27 \%$ & $19.3 \%$ & 8.54 & 1.31 & 0.60 \\
\hline
\end{tabular}

I. All questions used a 10 point visual analogue rating format scale:

\section{Very Poor I-I-I-I-I-I-I-I-I-I Excellent}

2. To avoid response set bias, the questions in the Nursing Home Administrator Job Satisfaction Questionnaire were presented in a random order, and did not include domain headings.

This point brings up the issue of who would use the NHAJSQ. Individual NHAs may receive some benefit from understanding their own job satisfaction, relative to others in the field. More utility from the instrument may come from corporate entities using this instrument, and using the results to improve working conditions. Clearly, with a new instrument, relative or normative job satisfaction information is not available; although, our descriptive results do provide a starting point in this regard, providing information from a large sample of NHAs.
Some recent publications have highlighted the importance of NHAs in nursing homes (e.g., $[5,25])$. These studies show NHAs influence quality of care and turnover of other staff. Moreover, in a qualitative study McCarthy and Friedman [25] show NHAs are themselves sensitive to the work environment. The NHA-JSQ, in future studies, could further expand this line of research.

The domains included in the NHA-JSQ would seem to follow Herzberg's two-factor theory [26]. That is, this prior 
work suggested that employee motivation and satisfaction was based on hygiene factors and motivation factors, respectively. Hygiene factors include wages, inter-personal relations, and supervision. Motivation factors include responsibility, gaining recognition, and opportunity for advancement. Almost all of these factors are included in the NHA-JSQ. Herzberg further reasoned that factors causing satisfaction were different from those causing dissatisfaction, and that favorable hygiene factors are needed to avoid dissatisfaction and favorable motivation factors to provide satisfaction [26]. Future studies could examine these factors in NHAs, and whether the two factors influence the performance of administrators.

In addition, applicant attraction theories would also suggest that factors promoting job satisfaction can be significant for attracting new employees to the organization. That is, these theories would suggest that the job satisfaction of current employees is a signal influencing prospective future employees. Thus, further examining job satisfaction of NHAs may be useful for at least two reasons; first, an influx of new administrator talent into nursing homes may be beneficial; and second, we are experiencing a decline in numbers of qualified NHAs [27].

\section{Limitations}

The NHA-JSQ may be subject to some limitations. For example, no negatively worded items were used, so response-set bias may result (i.e., respondents using the same response for all categories). In addition, in developing this instrument, administrators may have provided socially appropriate responses. Without information from an existing instrument, it is also difficult to determine how our questionnaire performs, relative to the other generic instruments described previously. Results using classical test theory are sample-dependent. Item response theory (IRT) may provide further information on the properties of the NHA-JSQ [28].

We believe one benefit of the NHA-JSQ comes from the use of few questions and simple nature of the questions. The use of few questions and simple wording leads to the use of somewhat terse language; nevertheless, this approach was used with some success for elders (e.g., [20]), with apparently greater understanding and high response rates. Similar benefits for job satisfaction and NHAs are yet to be determined. Nevertheless, we should note that in on-going work with this instrument: response rates have been high ( $>70$ percent); NHA interviews have determined that the terse language is welcomed and extremely well understood; and, the graphic 1 to 10 response scale is liked.
In addition, we must be careful in addressing causal order. We maintain that NHA job satisfaction influences organizational performance, ability to change, and quality of care. However, the reverse may also be the case. That is, the causal order is ambiguous in these relationships.

\section{Conclusion}

Despite the limitations described above, we believe the NHA-JSQ provides a sound instrument for use in nursing homes. We have produced a short, psychometrically sound instrument. This is important because we were unable to find in the published literature an appropriate instrument for use in this long-term care setting.

Job satisfaction of NHAs has important implications for nursing home staff, the nursing home industry, and quality of care. Other studies have shown strong linkages between job satisfaction (dissatisfaction) and job performance and turnover [29]. The NHA-JSQ could be used to examine similar relationships for administrators (i.e., job (dis)satisfaction and job performance and turnover). Moreover, it is clear that NHAs have a pivotal position in nursing homes. It is our hope that the NHA-JSQ be used, first, to further show the importance of NHAs in improving nursing home care, and second, to further improve the working conditions for NHAs themselves.

\section{Competing interests}

The author(s) declare that they have no competing interests.

\section{Authors' contributions}

Nicholas Castle completed all of the work in this manuscript

\section{Acknowledgements}

All funding came from the University of Pittsburgh Research Development Funds

\section{References}

I. Grieshaber LD, Parker P, Deering J: Job satisfaction of nursing assistants in long-term care. The Health Care Supervisor 1995, 13(4): 18-28.

2. Eaton SC: Beyond 'unloving care:' Linking human resource management and patient care quality in nursing homes. International Journal of Human Resources Management 2000, 3:59I-616.

3. Institute of Medicine. In Quality of Care in Nursing Homes National Academy Press, Washington, D.C; 2001.

4. Singh DA, Amidon RL, Shi L, Samuels ME: Predictors of quality of care in nursing facilities. Journal of Long-Term Care Administration 1996, 24(3):22-26

5. Castle NG: Administrator turnover and quality of care in nursing homes. The Gerontologist 200I, 4 I (6):757-767.

6. Smith HL, Shortell SM, Saxberg BO: Administration: The critical long-term care variable. Health Care Management Review, Fall 1977:67-72.

7. Singh DA, Schwab RC: Retention of administrators in nursing homes: what can management do? The Gerontologist 1998, 38:362-369.

8. Ejaz FK, Straker JK, Fox K, Swami S: Developing a satisfaction survey for families of Ohio's nursing home residents. The Gerontologist 2003, 43(4):447-458. 
9. Irvine DM, Evans MG: Job satisfaction and turnover among nurses: Integrating research findings across studies. Nursing Research 1995, 44:246-253.

10. Smith PC, Hulin CL, Kendall LM, Locke EA: The development of a method of job satisfaction: The Cornell studies. In Studies in Personnel and Industrial Psychology 3rd edition. Edited by: Fleishman EA Bass AR. Homewood, IL: Dorsey Press; 1974.

II. Stamps PL, Piedmonte EB: Nurses and work satisfaction: An index for measurement. Ann Arbor, Ml: Health Administration Press Perspectives; 1986.

12. Boyt TE, Lusch RF, Naylor G: The role of professionalism in determining job satisfaction in professional services. Journal of Service Research 200I, 3(4):32I-330.

13. Chou SC, Boldy DP, Lee AH: Measuring job satisfaction in residential aged care. International Journal of Quality in Health Care 2002 I4(1):49-54

14. Gillies DA, Foreman M, Pettengill MM: Satisfaction of nurse managers in long-term care. Journal of Gerontogical Nursing 1996 22:33-40.

15. Coward RT, Hogan TL, Duncan RP, Horne CH, Hilker MA, Felsen LM: Job satisfaction of nurses employed in rural and urban long-term care facilities. Research in Nursing and Health 1995, [ 8(3):27|-284.

16. Castle NG, Banaszak-Holl JC: The effect of administrative resources on care in nursing homes. Journal of Applied Gerontology 2003, 22(3):405-424.

17. Best MF, Thurston N: Measuring nurse job satisfaction. Journal of Nursing Administration 2004, 34(6):283-290.

18. Patton MQ: Qualitative Research and Evaluation Methods Thousand Oaks, CA: Sage; 2002

19. Blegen MA: Nurses' job satisfaction: A meta-analysis of related variables. Nursing Research 1993, 42:36-41.

20. Castle NG, Engberg J: Response scales and satisfaction of elders. The Gerontologist 2004, 44(3):358-367.

21. Harrington $\mathrm{C}$, Carrillo $\mathrm{H}$ : The regulation and enforcement of federal nursing home standards, 1991-1997. Medical Care Research and Review 1999, 56(4):47|-494.

22. Straker J: Reliability of OSCAR occupancy, census, and staff data: A comparison with the Ohio Department of Health annual survey of long-term care facilities. Technical Report Series 3-01: Scripps Gerontology Center, Oxford OH 1999.

23. McHorney CA, Ware JE, Lu R, Sherbourne CD: The MOS 36-item short-form health survey (SF-36): III Tests of data quality, scaling assumptions, and reliability across diverse patient groups. Medical Care 1994, 32:40-66.

24. American Nurses Association: American Nurses Association staffing survey, 200I. 2002 [http://nursingworld.org/staffing/ ana pdf.pdf]. Accessed March 12, 2002

25. McCarthy J, Friedman LH: The significance of autonomy in the nursing home administrator profession: A qualitative study. Health Care Management Review 2006, 3 I ( I):55-63.

26. Herzberg F, Mausner B, Snyderman B: Motivation to Work. John Wiley and Sons; New York; 1959.

27. Pratt J: The disappearing administrator: Results of a national survey. Nursing Home and Long Term Care Management 2002, $5 I(4): 24-28$

28. Hulin CL, Drasgow F, Parsons CK: Item response theory: Applications to psychological measurement. Homewood, IL: Irwin; 1983.

29. Judge T, Thoresen C, Bono JE, Patton G: The job satisfaction-job performance relationship: $A$ qualitative and quantitative review. Psychological Bulletin 200I, I 27:376-407.

30. Murphy B: Nursing home administrators' level of job satisfaction. Journal of Healthcare Management 2004, 49:336-345

31. Parsons SK, Simmons WP, Penn K, Furlough M: Determinants of satisfaction and turnover among nursing assistants. The results of a statewide survey. Journal of Gerontological Nursing 2003, 29(3):5I-58.

32. Moyle W, Skinner CJ, Rowe G, Gork C: Views of job satisfaction and dissatisfaction in Australian long-term care. Journal of Clinical Nursing 2003, I 2(2): 168-176.

33. Chou SC, Boldy DP, Lee AH: Staff satisfaction and its components in residential aged care. International Journal for Quality in Health Care 2002, 14(3):207-217.
34. Will K, Simmons J: Ohio CNAs speak out. Enjoyment ranks high, pay low in satisfaction study. Provider 1999, 25(10): 107,109-110.

35. Atchison $\mathrm{JH}$ : Perceived job satisfaction of nursing assistants employed in Midwest nursing homes. Geriatric Nursing 1998, 19(3): 135-137.

36. Kiyak HA, Namazi KH, Kahana EF: Job commitment and turnover among women in facilities serving older persons. Research on Aging 1997, I 9(2):223-246.

37. Monahan RS, McCarthy S: Nursing home employment: The nurse's aide's perspective. Journal of Gerontological Nursing 1992, 18:13-16.

38. Grau L, Chandler B, Burton B, Kolditz D: Institutional loyalty and job satisfaction among nurse aides in nursing homes. Journal of Aging and Health |99|, 3(I):47-65.

39. Anderson MA, Aird TR, Haslam WB: How satisfied are nursing home staff? Geriatric Nursing 1991, March/April:85-87.

40. Humphris GM, Turner A: Job satisfaction and attitudes of nursing staff on a unit for the elderly severely mentally infirm, with change of location. Journal of Advanced Nursing 1989, 14:298-307.

4I. Mullins L, Nelson C, Busciglio $H$, Weiner $H$ : Job satisfaction among nursing home personnel: The impact of organizational structure and supervisory power. Journal of Long-Term Care Administration 1988, 16:12-18.

42. Deckard G], Hicks LL, Rountree BH: Long-term care nursing: How satisfying is it? Nursing Economics 1986, 4(4): 194-200.

43. Waxman HM, Carner EA, Berkenstock G: Job turnover and job satisfaction among nursing home aides. The Gerontologist I 984, 24(5):503-509.

44. Bergman R, Eckerling S, Golander H, Sharon R, Tomer A: Staff composition, job perceptions, and work retention of nursing personnel in geriatric institutions. International Journal of Nursing Studies 1984, 21 :279-293.

\section{Pre-publication history}

The pre-publication history for this paper can be accessed here:

http://www.biomedcentral.com/1471-2288/6/47/prepub
Publish with Bio Med Central and every scientist can read your work free of charge

"BioMed Central will be the most significant development for disseminating the results of biomedical research in our lifetime. "

Sir Paul Nurse, Cancer Research UK

Your research papers will be:

- available free of charge to the entire biomedical community

- peer reviewed and published immediately upon acceptance

- cited in PubMed and archived on PubMed Central

- yours - you keep the copyright

Submit your manuscript here:

http://www.biomedcentral.com/info/publishing_adv.as
BioMedcentral 